\title{
Cataleptic Effect of 61-91 Beta-Lipotropic Hormone in Rat
}

\author{
T MOTOMATSU, M. LIS, N SEIDAH AND M. CHRÉTIEN
}

SUMMARY: Intraventricular administration of a peptide from ovine pituitaries whose structure is identical to the 61-91 $C$-terminal portion of beta-lipotropic hormone (61-91 beta-LPH) induced catalepsy, muscular hypertonus and analgesia in rats. Naloxone inhibited both the analgesic and cataleptic effects. l-dihydroxyphenylalanine (l-DOPA) completely prevented the cataleptic effect. The cataleptic effect of 61-91 beta-LPH was potentiated by $1-5$ hydroxytryptophan (5-HTP).

RÉSUMÉ: L'administration intraventriculaire d'un peptide isolé d'hypophyses de mouton, peptide dont la structure est identique au fragment carboxy-terminal 61-91 de la béta-lipotropine produit de la catalepsie, de l'hypertonie musculaire et de l'analgésie chez le rat. La naloxone inhibe les effets analgésiques et cataleptiques. La l-dihydroxyphenylalanine (l-DOPA) a prévenu totalement l'effet cataleptique. Celui-ci était par contre potentialisé par du l-5-hydroxytryptophane (5-HTP).
From the Clinical Research Institute of Montreal, 110 Pine Avenue West, Montreal, Quebec.

Reprint requests to Dr. M. Chrétien, Clinical Research Institute of Montreal, 110 Pine Avenue, West, Montréal H2W 1R7, Canada.

Work supported by a Program Grant from the Medical Research Council of Canada.

Accepted for publication Oct. 7, 1976.
The recent discoveries of peptides with morphine-like activity (Hughes, 1975; Pasternak et al., 1975; Terenius and Wahlstrom, 1975; Teschemacker et al., 1975; Cox et al., 1975) and their structural relationship to beta-LPH (Hughes et al., 1975; Simantov and Snyder, 1976) raised questions about their physiological significance, their origin and possible therapeutic use. The specific regional (Hughes, 1975; Pasternak et al., 1975; Simantov et al., 1976a) and subcellular (Simantov et al., 1976b) distributions of these peptides in the brain suggest their neurophysiological role in the central nervous system.

Four such peptides have been identified. Methionine-enkephalin and leucine-enkephalin were isolated from porcine and bovine brains (Hughes et al., 1975; Simantov et al., 1976a). Alpha-endorphine was subsequently found in porcine hypothalamic and pituitary extracts (Guillemin, 1976). Moreover, 61-91 beta-LPH was identified in porcine, camel, ovine and human pituitaries (Hughes, 1975; Guillemin et al., 1976; Li and Chung, 1976; Bradbury et al., 1976; Chrétien et al., in press; Seidah et al., 1976). Structurally, methionine-enkephalin corresponds to 61-65 fragment of beta- $\mathrm{LPH}$, and alpha-endorphine to 61-76 fragment of beta-LPH. All these peptides have morphine-like activity in both in vitro opiate bioassays and in competitive binding assays using brain opiate receptors.

In this article we report some central nervous effects of 61-91 betaLPH isolated from sheep pituitaries.

\section{MATERIALS AND METHODS}

61-91 beta-LPH was purified from ovine pituitaries as described in pre- vious reports (Chrétien et al., in press; Seidah et al, in press). Intraventricular cannulation was performed in $270 \backsim 300 \mathrm{~g}$ male Sprague-Dawley rats under pentobarbital anesthesia (Donaldson et al., 1971). The rats were used for experiments $24 \mathrm{~h}$ after cannulation. The peptides were dissolved in 20 $\mu \mathrm{l}$ of $5 \mathrm{mM}$ phosphate buffer $\mathrm{pH} 7.2$ containing $0.145 \mathrm{M} \mathrm{NaCl}$ and injected into the lateral ventricle at the rate of $0.2 \mu 1$ per sec. L-DOPA (100 $\mathrm{mg} / \mathrm{kg})$, 5-H TP $(100 \mathrm{mg} / \mathrm{kg})$ and Ro-4602 N'(DL-seryl)-N²-(2,3,4trihydroxybenzyl) - hydrazine (Ro-4-4602) $(50 \mathrm{mg} / \mathrm{kg})$ were administered intraperitoneally, dissolved in $0.9 \% \mathrm{NaCl}$. L-DOPA or 5-HTP were injected $30 \mathrm{~min}$ after the administration of Ro-4-4602. Forty min after the second injection, 61-91 beta-LPH was administered. Naloxone $(2 \mathrm{mg} / \mathrm{kg})$ was administered subcutaneously, 15 min before the injection of 61-91 beta-LPH. In a second series of experiments, naloxone, 26 nmol, was injected intraventriculary at the same time as 61-91 beta-LPH.

Catalepsy was assessed by the ability of the rat to maintain the imposed position with front limbs on a $10 \mathrm{~cm}$ high horizontal bar. The animal maintaining the position for more than $30 \mathrm{sec}$ was judged as positive. The maximum length of time the rat kept the position was also recorded and used as a measure of intensity. Analgesic effect was evaluated by pricking the tail with forceps. Absence of any response by the animal was judged as positive. All untreated rats responded to this stimulation with squeak and movement. The rats were tested every 5 min during the first $30 \mathrm{~min}$ and every $10 \mathrm{~min}$ until the symptoms disappeared. All animals were observed 


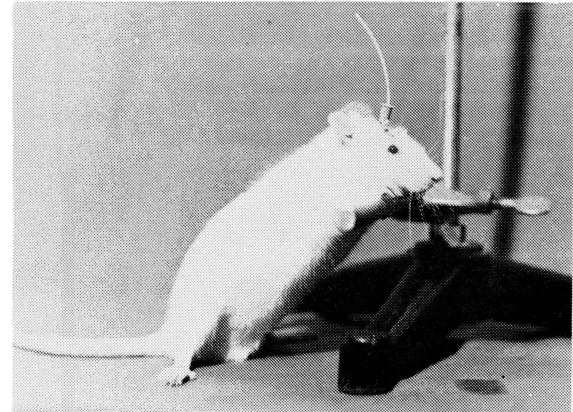

Figure 1-A rat with catalepsy induced by 61-91 beta-LPH. $13 \mathrm{nmol}$ of 61-91 beta-LPH was administered into the lateral ventricle through implanted cannula. The photograph was taken 1 $h$ after the injection.

for at least $100 \mathrm{~min}$. In all the observations three positive results were required as minimal criteria for declaring the symptoms as positive.

\section{RESULTS}

The typical demonstration of a cataleptic reaction induced by $61-91$ beta-LPH is shown in Fig. 1. Table 1 presents the dose effect of 61-91 beta-LPH for catalepsy. The ED-50 (Litchfield and Wilcoxon, 1949) was calculated as $5.0 \mathrm{nmol}$ per rat with 95\% confidence limit of $2.8-8.5$.

Table 2 shows the catatonic effect of 61-91 beta-LPH at higher doses. The ED-50 was $25.0 \mathrm{nmol}$ per rat with 95\% confidence limits of 11-55. The potency ratio between the ED-50 for catalepsy and muscular hypertonus (catatonia) was 5.0 with $95 \%$ confidence limits of $1.9-12.9$. The cataleptic rats without muscular hypertonus responded rapidly to stimuli, such as high-pitched noise, with transient movements. The catatonic rats did not respond to any stimuli, and kept the abnormal postures. At the dose of $100 \mathrm{nmol}$ per rat fine tremor of the whole body was observed. The tremor was spontaneous and intermittent in some cases, or was induced by external stimuli in others.

In Table 3, we present the effect of L-DOPA, 5-HTP and naloxone on the catalepsy and analgesia caused by $13 \mathrm{nmol}$ of $61-91$ beta-LPH per rat (ED-96 for catalepsy). The pretreatment with L-DOPA completely -abolished the cataleptic effect of 61-91 beta-LPH. At this concentration, however, L-DOPA has no detectable effect on analgesia. In contrast, subcutaneous administration of naloxone $(2 \mathrm{mg} / \mathrm{kg})$ abolished the analgesia without affecting the cataleptic effect. The animals pretreated subcutaneously with this dose of naloxone seemed to show hyperalgesia more than analgesia. 5-HTP enhanced the cataleptic effect of 61-91 beta-LPH.

Table 4 shows an inhibitory effect of intraventircularly injected naloxone on the catalepsy induced by 13 nmol of 61-91 beta-LPH. Intraventricular administration of naloxone (26 nmol/rat) together with 61-91 beta-LPH $(13 \mathrm{nmol} / \mathrm{rat})$ delayed the onset and decreased the occurrence, duration and maximum time. In this experiment we also examined the effect of 61-91 beta-LPH on the corneal reflex. The corneal reflex was lost within $10 \mathrm{~min}$ after the administration of 61-91 beta-LPH. Naloxone administration delayed the onset to about $40 \mathrm{~min}$.

We were, however, unable to reproduce the cataleptic behavior in our experimental conditions using synthetic methionine-enkephalin at doses up to $200 \mathrm{nmol}$ per rat.

\section{DISCUSSION}

It has been reported that opiates have specific receptors in the animal brain (Pert and Snyder, 1973). Analgesia, catalepsy and muscular rigidity were induced by morphine and some of its analogs (Banerjee et al, 1968; Fog, 1970). The regional distribution of morphine-like peptide in monkey brain revealed the highest concentration in the extrapyramidal system (Simantov et al., 1976b), which is considered a regulatory center of motor function.

Our results suggest a possible physiological function of morphinelike peptides in the control of motor function. We also demonstrated the differentiation of catalepsy and muscular hypertonus by different doses. These results are consistent with observations using morphine and its analogs (Costal and Naylor, 1974). The inhibitory effect of naloxone, a specific opiate antagonist, on the cataleptic and analgesic effects of 61-91 beta-LPH indicates the action of this peptide on opiate receptors. In addition, our results demonstrated an opposite effect of L-DOPA
DOSE EFFECT OF 61-91 BETA-LPH FOR CATALEPSY IN RAT

\begin{tabular}{|c|c|c|c|c|c|c|c|c|}
\hline \multirow{3}{*}{$\begin{array}{c}\text { Dose } \\
\mathrm{nmo1/ \textrm {rat }} \\
2\end{array}$} & \multirow{2}{*}{$\begin{array}{l}\text { Number } \\
\text { of rats }\end{array}$} & \multirow{2}{*}{$\begin{array}{c}\text { Number } \\
\text { cataleptic }\end{array}$} & \multicolumn{3}{|c|}{ Onset } & \multicolumn{3}{|c|}{ Duration } \\
\hline & & & min & $( \pm \mathrm{SE}$ & & min & & $S[)$ \\
\hline & 6 & 2 & 15 & \pm & 10 & 25 & \pm & 15 \\
\hline 4 & 6 & 2 & 25 & \pm 1 & 15 & 30 & \pm & 10 \\
\hline 6 & 6 & 4 & 24 & \pm & 4 & 88 & \pm & 11 \\
\hline 8 & 6 & 4 & 15 & \pm & 2 & 64 & \pm & 18 \\
\hline 10 & 6 & 5 & 9 & \pm & 1 & 105 & \pm & 27 \\
\hline
\end{tabular}

Each dose of 61-91 beta-LPH was administered intraventricularly. The values of ED-16, ED-50 and ED-84 were 0.6, 5.0 (95\% confidence limit of 2.9-8.5) and $9.4 \mathrm{nmol}$ per rat respectively
DOSE EFFECT OF 61-91 BETA-LPH FOR MUSCULAR HYPERTONUS IN RAT

\begin{tabular}{ccccc}
\hline $\begin{array}{c}\text { Dose } \\
\text { nmol/rat }\end{array}$ & $\begin{array}{c}\text { Number } \\
\text { of rats }\end{array}$ & catatonic & Onset & $\begin{array}{c}\text { Duration } \\
\text { min } \pm \mathrm{SE})\end{array}$ \\
\hline 1.6 & 6 & 0 & - & - \\
3.2 & 6 & 0 & - & - \\
6.3 & 6 & 1 & 25 & 15 \\
12.5 & 6 & 2 & $23 \pm 8$ & $63 \pm 3$ \\
25 & 6 & 3 & $18 \pm 11$ & $72 \pm 11$ \\
50 & 6 & 5 & $18 \pm 3$ & $99 \pm 17$
\end{tabular}

Each dose of 61-91 beta-LPH was administered intraventricularly. The values of ED-16, ED-50 and ED-84 were 7.0, 25.0 (95\% confidence limit of $11-55$ ) and 44 nmol per rat respectively 
TABLE 3

EFFECTS OF I-DOPA, 5-HIP AND SUBCUTANEOUSLY ADMINISTERED

NALOXONE ON THE CATALEPTIC

AND ANALGESIC EFFECT OF 61-91 BETA-LPH IN RAT

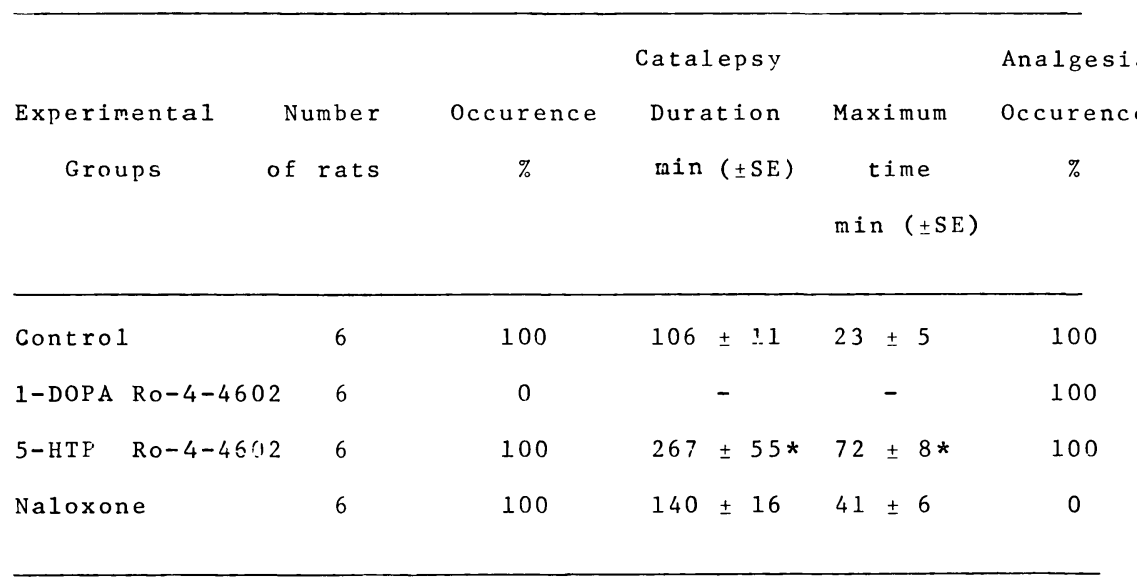

L-DOPA, Ro-4-4602, 5HTP and 61-91 beta-LPH were administered as described in materials and methods. Naloxone was injected subcutaneously 15 rin prior to 61-91 beta-LPH. Control aninals vere injected with $2.5 \mathrm{ml}$ of $0.9 \% \mathrm{NaCl} 70$ min before the administration of 61-91 beta-I.PH. The maximum time is the longest time the cataleptic animal maintained the imposed position on the bar. * $\quad F<0.01$

TABLE 4

EFFECT OF INTRAVENTRICULAR ADMINISTRATION OF NALOXONE ON THE CATALEPTIC EFFET OF 61-91 BETA-LPH

$\begin{array}{ccccc}\text { Experimental } & \text { Number } & \text { Occurence } & \text { Onset } & \text { Duration } \\ \text { Groups } & \text { of rats } & \text { min }( \pm S E) & \text { min ( } \pm S E) \text { min ( } \pm S E)\end{array}$

\begin{tabular}{llcccc}
\hline Control & 6 & 6 & $6 \pm 0.9$ & $118 \pm 16$ & $54 \pm 12$ \\
Naloxone & 6 & 4 & $40 \pm 2.4 * *$ & $28 \pm 7.5 * * 6 \pm 1.6 *$ \\
\hline
\end{tabular}

61-91 beta-LPH (13 nmol/rat) and naloxone (26 nmol/rat) was administered simultaneously in the lateral ventricula.

* $\quad P<0.02$

$* * \mathrm{P}<0.01$ and 5-HTP on the catalepsy induced by 61-91 beta-LPH. This is consistent with the report suggesting the reciprocal actions of dopaminergic and serotonergic systems in catalepsy (Kostowski et al., 1972; Costal and Naylor, 1975).

One might also consider the possibility of the pathophysiological involvement of morphine-like peptides in some neuropsychological diseases which have symptoms similar to morphinomimetic drugs.

\section{ACKNOWLEDGMENTS}

We are indebted to Dr. K. Izumi for constant support and advice. We are also grateful to Dr. A. Barbeau for providing L-DOPA, 5-HTP and R0-4-4602. We acknowledge the secretarial expertise of Mrs. D. Marcil.

\section{REFERENCES}

BANERJEE, U., BURKS, T. F., FELDBERG, W and GOODRICH, C. A. (1968). Temperature effects and catalepsy produced by morphine injected into the cerebral ventricles of rabbits. Brit. J. Pharmacol. 33: 544-551.

BRADBURY, A. F., SMYTH, D. G. and SNELL, C. R. (1976). Lipotropin: precursor to two biologically active peptides. Biochem. Biophys. Res. Comm. 69: 950-956.

CHRETIEN, M., BENJANNET, S. DRAGON, N., SEIDAH, N. G. and LIS, M. Isolation of peptides with opiate activity from sheep and human pituitaries: relationship to beta-lipotropin. Biochem. Biophys. Res. Commun. (in Press).

COSTAL, B. and NAYLOR, R. J. (1974). A role for the amygdala in the development of the cataleptic and stereotypic actions of the narcotic agonists and antagonists in the rat. Psychopharmacologia (Berl.) 35: 203-213.

COSTAL, B. and NAYLOR, R. J. (1975). Serotonergic involvement with the stereotypy/catalepsy induced by morphine-like agents in the rat. J. Pharm. Pharmac. 27: 67-69.

COX, B. M., OPHEIM, K. E., TESCHEMACHER, H. and GOLDSTEIN, A. (1975). A peptide-like substance from pituitary that acts like morphine. Purification and property. Life Science 16: 1777-1782.

DONALDSON, J., ST-PIERRE, T., MINNICH, J. and BARBEAU, A. (1971). Seizures in rats associated with divalent cation inhibition of $\mathrm{Na}^{+}-\mathrm{K}^{+}$-ATP'ase. Can. J. Biochem. 49: 1217-1224.

FOG, R. (1970). Behavioral effects in rats of morphine and amphethamine and of a combination of two drugs. Psychopharmacologia (Berl.) 16: 305-312. 
GUILLEMIN, R., LING, N. and BURGUS, R. (1976). Endorphines, peptides, d'origine hypothalamique et neurohypophysaire à activité morphinomimétique. Isolement et structure moléculaire de 1-alphaendorphine. C. R. Acad. Sc. Paris 282: 783-785.

HUGHES, J., SMITH, T W., KOSTERLITZ, H. W., FOTHERGILL, L. A., MORGAN, B.A. and MORRIS, H. R. (1975). Identification of two related pentapeptides from the brain with potent opiate agonist activity. Nature 258: 577-579.

HUGHES, J (1975). Isolation of an endogenous compound from the brain with pharmacological properties similar to morphine. Brain Res. 88: 295-308.

KOSTOWSKI, W., GUMULKA, W and CZLONKOWSKI, A. (1972). Reduced cataleptogenic effects of some neuroleptics in rats with lessioned midbrain raphe and treated with p-chlorophenylalanine. Brain Res. 48: 443-446.
LI, C. H., and CHUNG, D. (1976). Isolation and structure of an untriakontapeptide with opiate activity from camel pituitary glands. Proc. Nat. Acad. Sci. U.S.A. 73: 1145-1148.

LITCHFIELD, J. T and WILCOXON, F. (1949). A simplified method of evaluating dose effect experiments. Pharmacol. Exp. Therap. 36: 99-113.

PASTERNAK, G. W., GOODMAN, R., and SNYDER, S. H. (1975). An endogenous morphine-like factor in mammalian brain. Life Science 16: 1765-1769.

PERT, C. B. and SNYDER, S. H. (1973). Opiate receptor: Demonstration in nervous tissue. Science 179: 1011-1014.

SEIDAH, N. G., LIS, M., GIANOULAKIS, C., SCHILLER, P. and CHRETIEN, M. (1976). Fragment of sheep beta-lipotropin with morphine-like activity. Lancet 1:1017.

SEIDAH, N. G., LIS, M., GIANOULAKIS, C., ROUTHEIR, R., BENJANNET, S., SCHILLER, P. W. and CHRETIEN, M. Morphine-like activity of sheep beta- lipotropin and of its fragments. Can. J. Biochem. (in Press).

SIMANTOV, R., KUHAR, M. J., PASTERNAK, G. W and SNYDER, S. H (1976a). The regional distribution of a morphine-like factor enkephalin in monkey brain. Brain Res. 106: 189-197

SIMANTOV, R., SNOWMAN, A. M. and SNYDER, S. H. (1976b). A morphine-like factor enkephalin in rat brain; subcellular localization. Brain Res. 107: 650-657

SIMANTOV, R. and SNYDER, S. H. (1976). Isolation and structure identification of a morphine-like peptide "enkephalin" in bovine brain. Life Sci. 18: 781-788.

TERENIUS, L. and WAHLSTROM, A. (1975). Morphine-like ligand for opiate receptors in human CSF Life Science 16: 1759-1764.

TESCHEMACKER, H., OPHEIM, K. E., COX, B. M. and GOLDSTEIN, A. (1975). A peptide-like substance from pituitary that acts like morphine. Life Science 16: 1771-1776. 